\title{
Parental care in captive Brandt vole (Lasiopodomys brandti Radde, 1861)
}

\author{
Vladimir S. Gromov
}

\begin{abstract}
In 10 male-female pairs observed under laboratory conditions, both parents were found to contribute to the care of young during the whole observation period (21 days from parturition) divided into four rearing periods (stages): days 2-6, 7-11, 12-16 and 17-21, respectively. All pairs exhibited permanent nest cohabitation. Paternal activities included nest construction, food caching, huddling over, brooding and grooming the young. There was slight sex differences in total time spent in the nest, but males spent alone in the nest more time than did females. Total time of pup grooming in females was commonly greater than in males. Besides, frequency of manipulations with bedding and bringing nest material to the nest in females were greater than in males. However, the rate of parental activity of males in pup grooming during $3^{\text {rd }}$ stage as well as in manipulations with bedding during $4^{\text {th }}$ stage was found to be similar to that one of females. Besides, males were more active in parental retrieving than females. In L. brandti the biparental care of young with a high direct paternal contribution seems to be associated with family group mode of life of this species. Parental care of Brandt vole is discussed in comparison with that one of other vole species.
\end{abstract}

KEY WORDS: Brandt vole, parental care, paternal contribution, time sharing, grooming, nest construction.

VladimirS.Gromov [gromov@sevin.chg.ru], A.N. Severtsov Institute of Ecology and Evolution, Russian Academy of Sciences, Leninskii pr. 33, Moscow 119071, Russia.

\section{Забота о потомстве у полевки Брандта (Lasiopodomys brandti Radde, 1861) в лабораторных условиях}

\section{В.С. Громов}

РЕЗЮМЕ. Под наблюдением в лабораторных условиях находились 10 пар полевки Брандта, в которых самки принесли по первому выводку. Наблюдения проводили в течение 20 дней, начиная со второго дня после рождения детенышей. Для анализа изменений родительского поведения по мере постнатального развития детенышей общий период наблюдений разделили на четыре стадии: 2-6-й день, 7-11-й день, 12-16-й день и 17-21-й день. Во всех парах самки и самцы занимали общее гнездо. Родительская забота заключалась в скучивании с детенышами и их обогревании, груминге (вылизывании) детенышей, гнездостроении и доставке корма в гнездо. Самцы и самки находились в гнезде с детенышами приблизительно равное количество времени, однако самцы дольше оставались с детенышами в периоды отсутствия самок. Самки, в целом, более активны в вылизывании детенышей и гнездостроении в сравнении с самцами. Вместе с тем продолжительность вылизывания детенышей на 12-16-й день и частота манипуляций с гнездовым материалом на 17-21-й день у самцов и самок были одинаковыми. Кроме того, самцы активнее самок затаскивали детенышей в гнездо, если они выползали наружу. Высокий родительский вклад самок и, в особенности, самцов у полевки Брандта, по всей видимости, связан с семейно-групповым образом жизни этого вида. Обсуждаются особенности родительского поведения полевки Брандта в сравнении с другими видами полевок.

КЛЮЧЕВЫЕ СЛОВА: полевка Брандта, родительское поведение, дифференцированный родительский вклад, груминг, гнездостроение.

\section{Introduction}

During the last three-four decades, many zoologists pay an increasing attention to the parental behavior of rodents. Sex and species differences in this behavior as well as proximate and ultimate mechanisms underlying them are of the great interest for many ecologists and ethologists. Among the rodents, only few vole species have been involved in these investigations. This article focuses on the parental care behavior of the Brandt vole, Lasiopodomys brandti. The initial impetus for this investigation was the observation that, in the laboratory, male Brandt voles participate in many aspects of parental care, like do males of some other vole species being the subjects of previous studies - prairie vole (Microtus ochrogaster), mandarin vole (Lasiopodomys mandarinus) and Guenther vole (Microtus guentheri) (Thomas \& Birney, 1979; Getz \& Carter, 1996; Lon- 
stein \& De Vries, 1999; Smorkatcheva, 2003; Libhaber \& Eilam, 2004). As for the Brandt vole, the extent to which parental care, including paternal one, occurs and what it means to the life history of this species has not previously been considered.

Very little data are available on ecology and behavior of Brandt vole in nature. During the reproductive period this species is known to form family groups consisting of one adult male and one or two-three females (Shi et al., 1998; Wan et al., 1998; Zöphel, 1999). Judging from observations in large open enclosures (Gromov, 2003), each family group occupies a defended territory. In case of a complex family group including several reproducing females, every the female protects individual home range as a part of complex male's territory encompassing ranges of the females. Social bonds between mates as well as between parents and their offspring were found to be relatively strong (Gromov, 2001, 2002).

It is well known that paternal care is expected in species forming monogamous pairs (Kleiman, 1977) or one-male harems (Eisenberg et al., 1972). Both cases are consistent with the reproductive strategy of the Brandt vole. In other Lasiopodomys species, namely $L$. mandarinus, males exhibited all the patterns of direct (with exception of nursing) and indirect care of young with high paternal investment (Smorkatcheva, 2003). Thus, high paternal investment might be suggested for the Brandt vole, too.

In this study, amount of parental care in the Brandt vole was measured as well as its division between the female and male, in order to determine amount of parental investment and whether there is a typical pattern of sharing investment among partners. Specifically, following questions were addressed: Do the female and male share caretaking equally? Whether the repertoire of the parental behavior of females and males is similar? Does the amount of parental investment depend on litter size?

\section{Materials and methods}

Animals and housing conditions. Animals used in this study were enclosure-bred descendants of stock originally captured in Buryatiya (Southern Siberia) in 1984-1990. Duration of pregnancy in Brandt voles is 21 days. Observations were carried out on 10 primiparous females and their mate males. All the animals used in the study were in good physical condition. Males were marked by clipping the spot of fur on their back. Each pair was housed in a $60 \times 35 \times 20 \mathrm{~cm}$ plastic cage with wooden nest chamber and wood shavings as bedding. All animals were maintained on natural photoperiod varying from $12 \mathrm{~L}: 12 \mathrm{D}$ to $16 \mathrm{~L}: 8 \mathrm{D}$, i.e. with a long light phase. Animals were fed on mixture of oats and sunflower seeds and fresh vegetables (carrot, cabbage, beetroots, and apples). Years of experience in maintaining lab colonies of Brandt voles at the Institute field station have shown that provision of water is unnecessary if sufficient fresh vegetables are provided.
When the females were nearing parturition (4-7 days before birth of the litter), each pair was transferred to a $60 \times 30 \times 35 \mathrm{~cm}$ glass aquarium with two wooden nest chambers $(15 \times 12 \times 8 \mathrm{~cm})$ and wood shavings as bedding. Every nest chamber was equipped with transparent plastic top to allow direct observation of the animals. This aquarium was placed in a quiet room with natural (uncontrolled) illumination (from 12L:12D to 16L:8D) during the test period. Animals were fed $a d$ lib as described above.

Behavioral observations. All observations started within the period from 15:00 to 23:00, the time of peak activity in this species under laboratory conditions (Gromov, 2001), and the beginning of every next observation was shifted by $1-2 \mathrm{~h}$ to eliminate the effect of starting time. During total observation period, the aquarium with a test pair was additionally illuminated with $25 \mathrm{~W}$ electric lamp attached in $1 \mathrm{~m}$ above the aquarium. Each family group was observed on the day 2 postpartum and thereafter every 1-2 days, each for $1 \mathrm{~h}$ or a bit more. Exact time at which every parent individual left or entered nest chamber was recorded. This information was used to calculate total time spent with young for both parents, and total time spent alone in the nest chamber by the female and male. Besides, following behaviors were recorded for both parents: duration of mate or pup grooming (licking), frequency of pup retrieval, frequency of manipulations with bedding in the nest chamber, frequency of bringing nest material (wood shavings) into the nest chamber, frequency of bringing of food into the nest (food cashing).

Data analysis. Data collected were grouped into four rearing periods (stages) in dependence on age of pups: days 2-6, days 7-11, days $12-16$ and days $17-$ 21 , with three $1 \mathrm{~h}$ observation sessions per each stage for each pair. Interactions between sex (female or male), rearing period $(1,2,3,4)$ and observation time $(16: 00$, 18:00, 20:00, 22:00) were analyzed using $2 \times 4 \times 4$ factorial ANOVA. To obtain a better fit to normal distribution, analysis was carried out on square root transformation of duration and on a natural logarithmic transformation of frequency. Spearmen rank order correlations (R) were conducted between numbers of pups in litters and mean values of each behavioral parameter. As not all the variables were normally distributed, the Wilcoxon matched pairs test and Mann-Whitney U test were used to assess the significance of differences between sexes (for each stage as well as for the total rearing period) and between stages (for each sex). An average value of each parameter was calculated from three observation sessions to provide a mean value $(\mathrm{M} \pm \mathrm{SE})$ of the parameter for each rearing period for each parent and its behavior. In all statistical comparisons, alpha level was set to 0.05 .

\section{Results}

Male-female interactions. No overt aggressive interactions between mates were recorded. Despite presence of two nest chambers in the test aquarium, all pairs 
demonstrated postpartum nest cohabitation: every family pair permanently occupied one preliminarily chosen nest chamber, and females never prevented males from entering the nest after parturition. Moreover, in five of ten pairs rearing pups, female demonstrated anxiety and irritability when male left the nest chamber. In this situation, the female tried to retrieve male into the nest holding the male's side or back with incisors and pulling him to the nest chamber. If the male entered the nest and did not try to come out, female settled down. Such a behavior occurred usually up to 7th-9th day after parturition, and was observed in two males in relation to their mate females as well.

Both females and, especially, males frequently groomed their mate partners in the nest. The rate of mate grooming in males (on average $2.5 \pm 0.5$ per $1 \mathrm{~h}$ ) was found to be essentially greater than that of females (on average $0.9 \pm 0.2$ per $1 \mathrm{~h}$ ): the difference is significant, Wilcoxon matched pairs test, $\mathrm{n}=10, \mathrm{z}=1.988, p=$ 0.047 . As for duration of mate grooming, average values of this parameter were nearly equal in males and females: $8.4 \pm 0.5 \mathrm{~s}(\mathrm{n}=185)$ and $9.1 \pm 1.5 \mathrm{~s}(\mathrm{n}=75)$, respectively; sex difference in this case is not significant: Mann-Whitney U test, $\mathrm{z}=-1.842, \mathrm{p}=0.064$.

Repertoire of parental behavior. The repertoire of parental behaviors demonstrated by males was essentially identical to that one of females. Males displayed all the patterns of direct care of young with exception of nursing: huddling over, grooming (licking) and retrieving the pups. Both females and males displayed a kyphosis posture when brooding pups. Such a posture was described for Rattus norvegicus (Stern \& Johnson, 1990), Microtus ochrogaster (Lonstein \& De Vries, 1999) and Lasiopodomys mandarinus (Smorkatcheva, 2003). Besides, males show indirect parental care including manipulations with bedding (push up and pull out wood shavings), collection and hoarding nest material. They also were engaged in food cashing.

Correlation of parental behaviors and litter size. Quantity of pups in the litters varied from 3 to 7 . All the parental behaviors were found to be independent on litter size: in females $-0.414<\mathrm{R}<0.605,0.084<\mathrm{p}<0.965$; in males $-0.606<\mathrm{R}<0.381,0.083<\mathrm{p}<0.999$.

Relative amount of parental care in males and females. There were no significant interactions between any factors (sex, rearing period and time of day) for any behaviors (Tab. 1).

Nest-residence. Significant sex differences were found in total time spent in the nest as well as in the time spent alone in the nest (Tab. 2): males spent significantly more time in the nest (Fig. 1A) during $1^{\text {st }}$ and $3^{\text {rd }}$ rearing periods $(\mathrm{z}>2.191, \mathrm{p}<0.028)$ as well as spent more time in the nest without the female (Fig. $1 \mathrm{~B})$ during $1^{\text {st }}, 2^{\text {nd }}$ and $3^{\text {rd }}$ rearing periods $(\mathrm{z}>1.958$, $\mathrm{p}<0.05)$. There were no essential differences in average values of these two parameters connected with particular stage: mean duration of nest-residence as well as mean time spent alone in females and males did not significantly change during the total observation period (Fig. 1).

As parents did not leave the nest for a long time, pups did not spend much time alone in the nest (Fig. 2):

Table 1. Interaction effects ( $\mathrm{p}$ values) between sex, rearing period, and time of day for captive Brandt voles.

\begin{tabular}{|l|c|c|c|c|}
\hline Behaviour & Sex $\times$ stage & Sex $\times$ time & Stage $\times$ time & Sex $\times$ stage $\times$ time \\
\hline Nest residence* & 0.866 & 0.746 & 0.914 & 0.824 \\
\hline Nest residence alone* & 0.904 & 0.848 & 0.746 & 0.912 \\
\hline Pup grooming* & 0.255 & 0.347 & 0.816 & 0.354 \\
\hline Manipulations with bedding** & 0.163 & 0.675 & 0.887 & 0.456 \\
\hline Bringing nest material** & 0.978 & 0.658 & 0.925 & 0.312 \\
\hline
\end{tabular}

* Mean duration

** Mean frequency

Table 2. Mean values $(\mathrm{M} \pm \mathrm{SE}$ ) of parental activities of female and male Brandt voles and their comparison for the whole rearing period.

\begin{tabular}{|l|c|c|c|c|}
\hline Behaviour & Females & Males & z score & p values \\
\hline Nest residence* & $53.2 \pm 1.0$ & $56.0 \pm 0.6$ & 1.851 & 0.064 \\
\hline Nest residence alone* & $2.7 \pm 0.4$ & $5.5 \pm 0.8$ & 4.493 & 0.00001 \\
\hline Pup grooming** & $79.2 \pm 10.3$ & $37.9 \pm 7.8$ & 4.469 & 0.00001 \\
\hline Manipulations with bedding*** & $6.4 \pm 1.4$ & $2.1 \pm 0.6$ & 4.108 & 0.0001 \\
\hline Bringing nest material*** & $1.6 \pm 0.2$ & $0.6 \pm 0.4$ & 2.248 & 0.025 \\
\hline
\end{tabular}

* Duration (minutes per $1 \mathrm{~h}$ )

** Duration (seconds per $1 \mathrm{~h}$ )

*** Frequency (number of occurrences per $1 \mathrm{~h}$ ) 

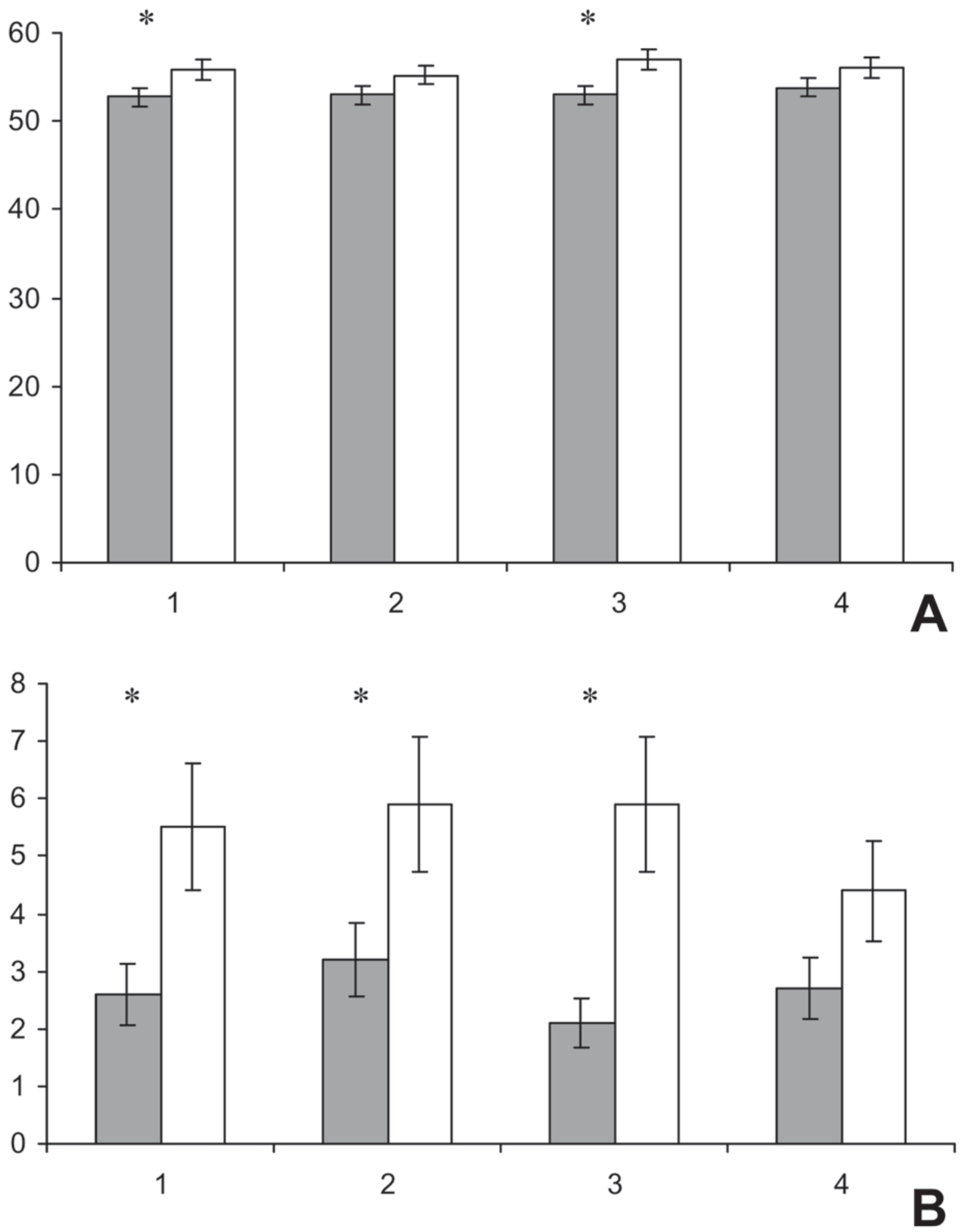

Figure 1. Total time (A) spent in the nest with pups of different ages by female (shaded bars) and male (open bars), and time spent alone in the nest $(B)$ by every parent $(\mathrm{M} \pm \mathrm{SE}$, minutes per $1 \mathrm{~h})$. Horizontal axis — rearing periods $(1-4){ }^{*}$ — significant sex difference $(\mathrm{p}<0.05)$. 


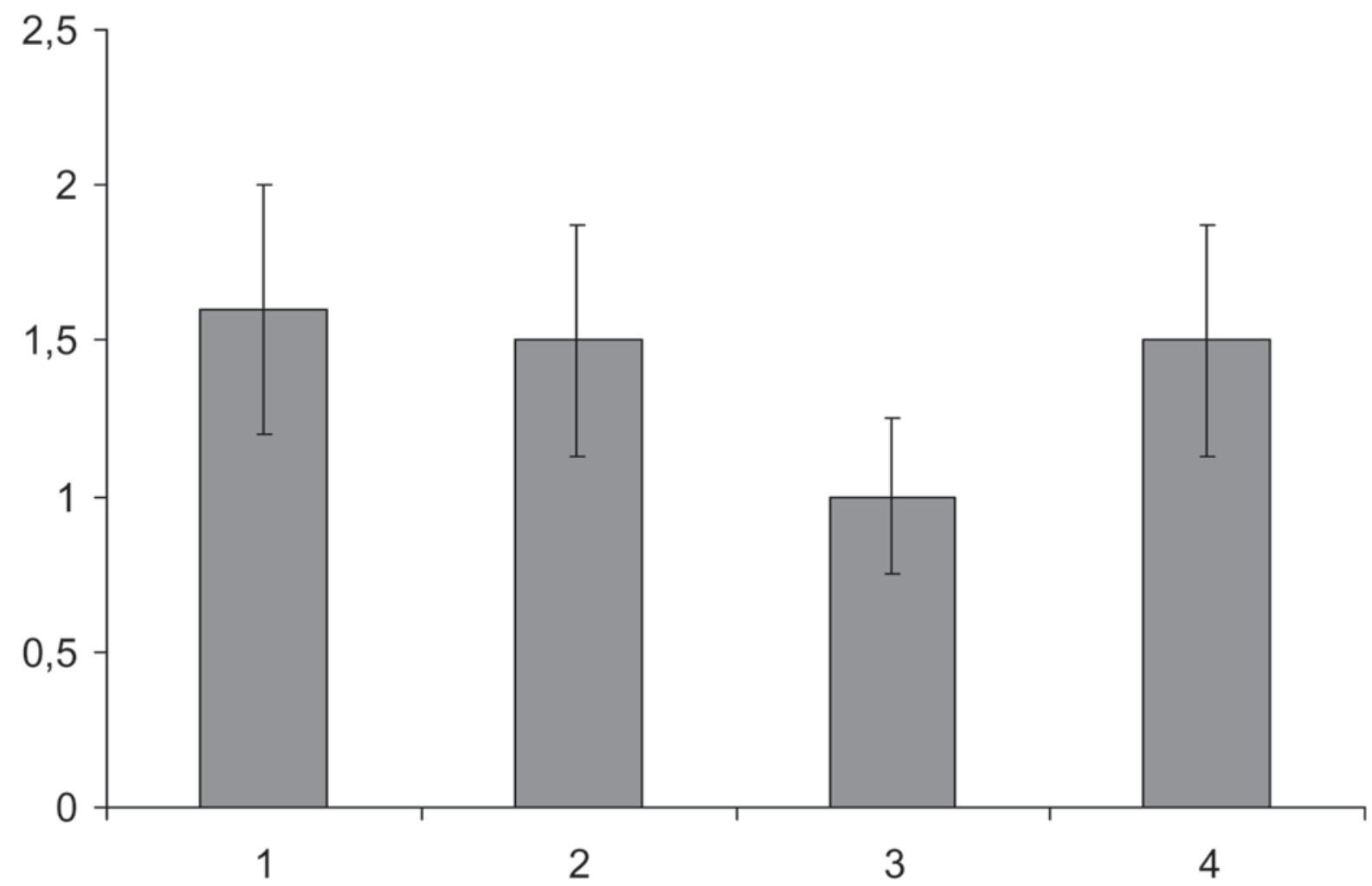

Figure 2. Total time $(\mathrm{M} \pm \mathrm{SE}$, minutes per $1 \mathrm{~h})$ spent by young in the nest without parents. Horizontal axis — rearing periods (1-4).

such periods were usually short and did not exceed 2 min on average (Tab. 2). There was no essential difference in mean values of this parameter over the whole observation period $(\mathrm{z}<1.120, \mathrm{p}>0.262)$.

Pup grooming. Females usually spent greater time grooming pups than did males except 3 rd rearing period (Fig. 3). Sex difference was significant for $1^{\text {st }}, 2^{\text {nd }}$ and $4^{\text {th }}$ rearing periods $(\mathrm{z}>1.955, \mathrm{p}<0.05)$ as well as for the total observation period (Tab. 2). Duration of pup grooming in females did not decline over the total observation period: differences in mean values of this parameter between stages are not significant, $z<1.421$, $p>0.155$. In contrast, duration of pup grooming in males increased from $1^{\text {st }}$ rearing period to $3^{\text {rd }}$ one, and further it declined (Fig. 3): the differences were significant in case of comparison of $3^{\text {rd }}$ stage with $1^{\text {st }}$ and $4^{\text {th }}$ ones: $\mathrm{z}>1.955, \mathrm{p}<0.05$.

Pup retrieval. This behavior was very rarely observed, and relevant data ( 9 cases) were not statistically analyzed. In 8 cases, parental retrieval was performed by males. One of the events occurred on the first day that pups started to leave the nest for foraging, but in other cases males responded to pups and retrieved them on 12-18 days. Females did not respond to pups occurring outside the nest except one case only.

Nest construction. Activity of parents in nest construction (bringing wood shavings for bedding into the nest chamber) was the most high during 1-2 days after transference of the pairs into the test aquarium. After parturition, such an activity was relatively low during the whole observation period (Fig. 4A, Tab. 2). Females were active in the nest construction during the entire observation period, and there were no significant differences in the rate of their activity between any two rearing periods. Males invested to the nest construction during first two stages only. Sex difference in the nest construction during $1^{\text {st }}$ and $2^{\text {nd }}$ rearing periods was not significant: $\mathrm{z}<1.113, \mathrm{p}>0.249$.

Nest maintenance. Manipulations with bedding inside the nest chamber were observed relatively frequently, especially in females (Fig. 4B, Tab. 2). Significant sex difference was found in the frequency of these manipulations during the whole observation period except $4^{\text {th }}$ stage: females were more active than males $(z>1.955$, $p<0.05)$. In females the frequency of manipulations with bedding essentially declined to the end of the entire observation period: comparison of the mean values of this parameter in $4^{\text {th }}$ rearing period with that ones in $1^{\text {st }}$ and $2^{\text {nd }}$ stages revealed significant differences $(\mathrm{z}>2.380$, $\mathrm{p}<0.017)$. As for males, their activity was relatively low and unaffected over the whole observation period.

Food cashing. Both females and males sometimes brought vegetables, oats and sunflower seeds into the nest chamber. Such an activity was irregular, and statistical analysis of this behavior was not performed. Totally, 15 events in females, and 11 events in males were recorded for the whole observation period. Usually, parents ate brought food themselves. 


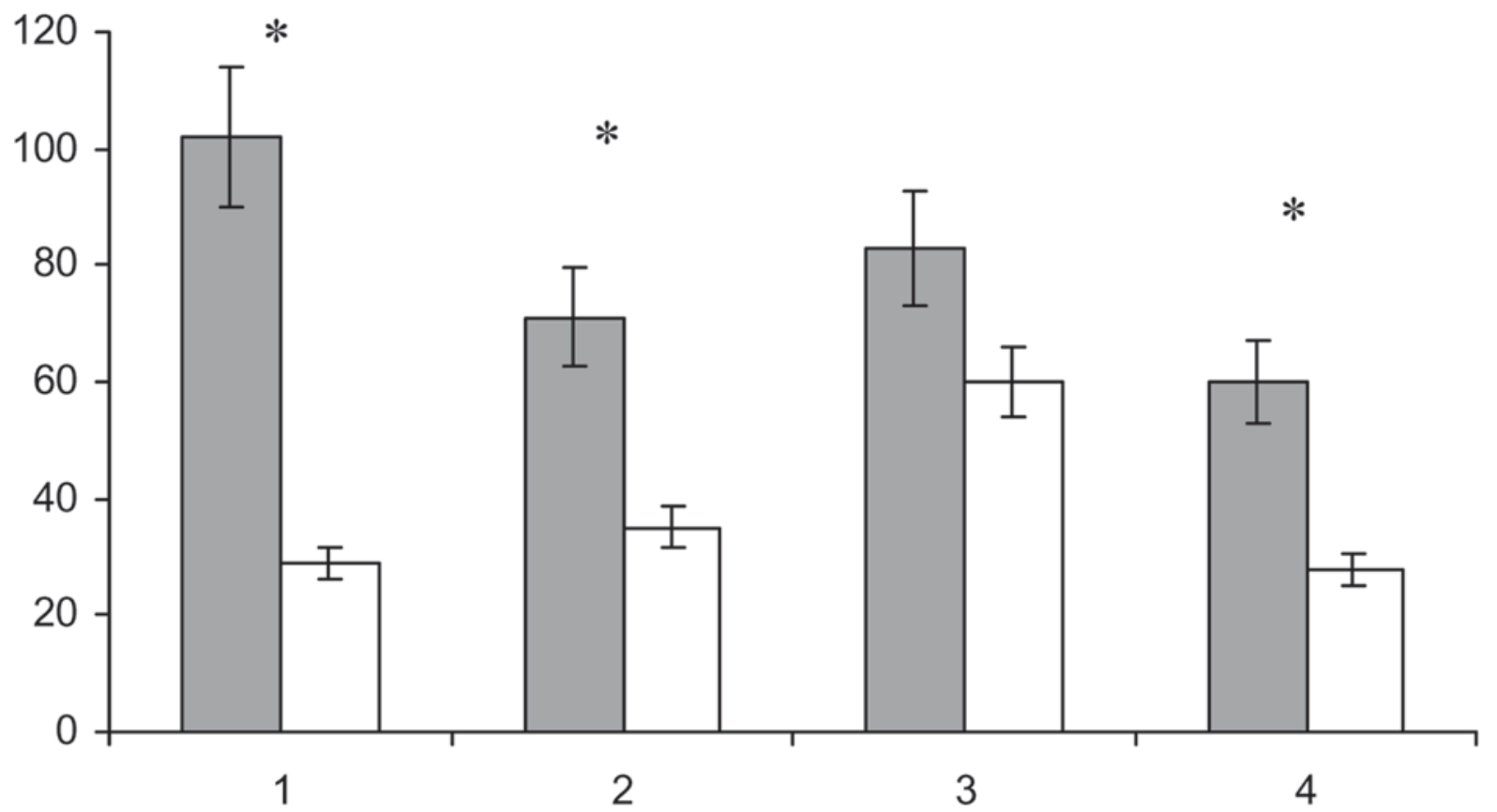

Figure 3. Duration of pup grooming $(\mathrm{M} \pm \mathrm{SE}$, seconds per $1 \mathrm{~h})$ in female (shaded bars) and male (open bars). Horizontal axis rearing periods $(1-4), *-$ significant sex difference $(\mathrm{p}<0.05)$.

Interrelation between parental behaviors. Cross correlation revealed that all the parental behaviors of males were independent ones. As for maternal behaviors, significant negative correlation was found between nest-residence and bringing nest material during $3^{\text {rd }}$ and $4^{\text {th }}$ rearing periods $(-0.743<\mathrm{R}<-0.695,0.022<\mathrm{p}<$ $<0.038$ ), and significant positive correlation was revealed between total time spent alone in the nest and manipulations with bedding during $2^{\text {nd }}$ rearing period $(\mathrm{R}=0.727, \mathrm{p}=0.027)$, as well as pup grooming during $4^{\text {th }}$ rearing period $(\mathrm{R}=0.870, \mathrm{p}=0.002)$. It means that the more time female spend in the nest alone the more frequently it manipulates with bedding and grooms pups. However, this relationship did not occur during the whole rearing period.

\section{Discussion}

The results of this study show that permanent nest cohabitation, similarity in parental repertoire of females and males, and high rate of caretaking, especially direct one, are characteristic of parental behavior of Brandt vole. Thus, the present findings indicate that the female and male share caretaking by spending time with the young, brooding over them and grooming them. Males huddle over pups displaying kyphosis posture like females. Surprisingly, pup retrieval was recorded mainly in males. Total time spent in the nest by males was the same one or even greater than that of females. Due to such a high rate of biparental care, infants spent alone in the nest very little time and received much amount of direct parental stimulation. In general, parental behaviors were found to be independent on litter size. There were no significant cross correlations between different parental behaviors as well, with exception of some maternal behaviors (nest residence, manipulations with bedding and pup grooming) during particular $\left(2^{\text {nd }}\right.$ and $\left.4^{\text {th }}\right)$ rearing periods.

I can also conclude that pair bonds in Brandt vole seems to be relatively strong because this species displays absence of overt aggressive interactions between mates, a high rate of allogrooming in mates, and their permanent nest cohabitation.

The present results show that some parental behaviors in Brandt vole changed during postnatal development of pups. Specifically, pup grooming in male increased to $3^{\text {rd }}$ rearing period and thereafter it decreased; manipulations with bedding in female and bringing wood shavings for the nest construction in male decreased over the total observation period. Unlike the parental behaviors listed above, time spent with young in both parents as well as pup grooming in females did not change during postnatal development. This finding is not in general agreement with previous studies in other vole species that report an overall decrease in parental behavior during the postnatal period (McGuire \& Novak, 1984; Oliveras \& Novak, 1986; Solomon, 1993; Lonstein \& De Vries, 1999; Smorkatcheva, 2003). Such a difference could be connected with a variability of parental behavior among different vole species, but it also might be that the parental responsiveness is dependent, to some extent, on various housing and observation conditions in different studies. 

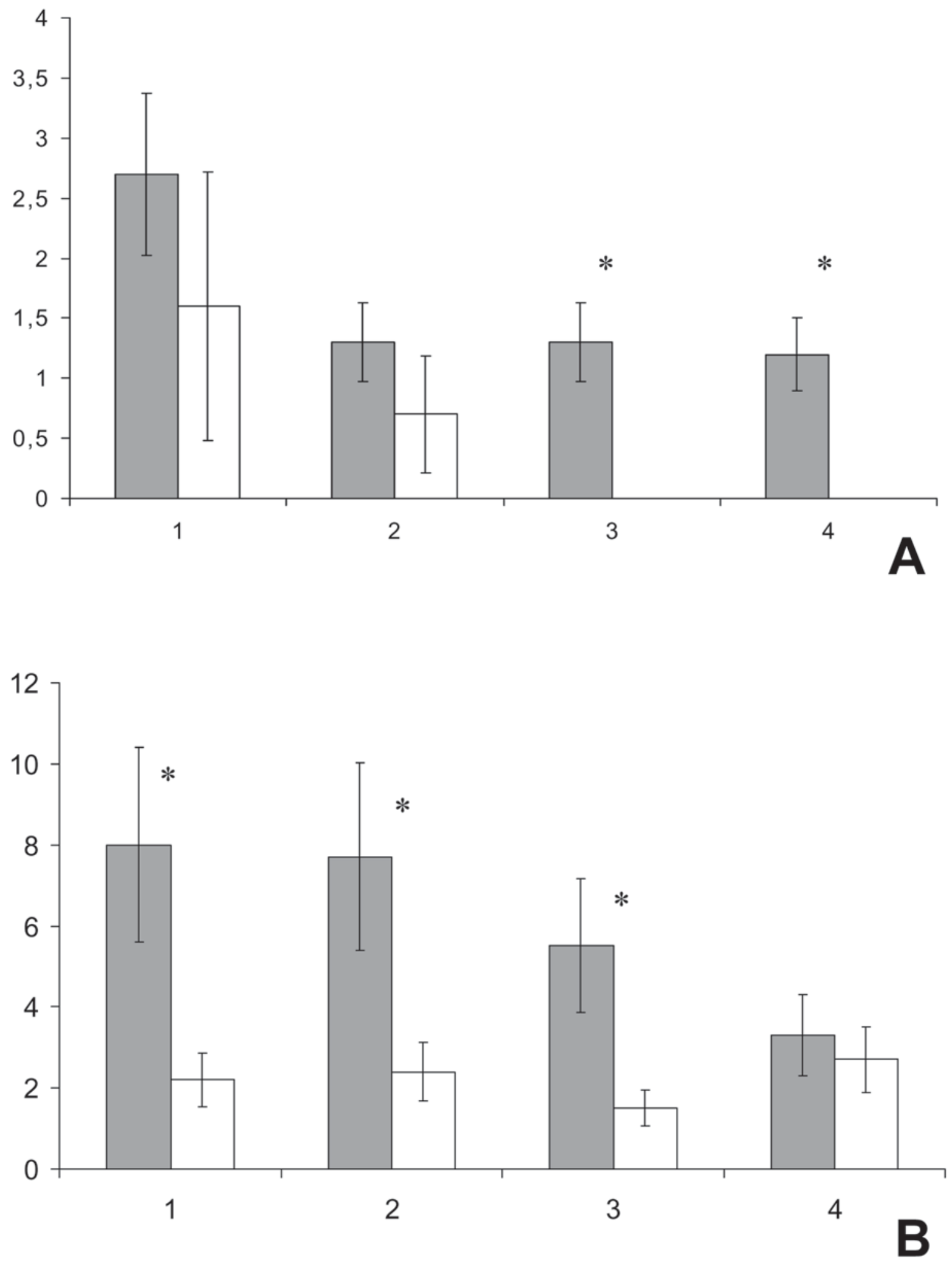

Figure 4. Frequency $(\mathrm{M} \pm \mathrm{SE}$ per $1 \mathrm{~h})$ of bringing wood shavings into the nest $(\mathrm{A})$ and manipulations with bedding (B) in female (shaded bars) and male (open bars). Horizontal axis — rearing periods $(1-4),{ }^{*}$ — significant sex difference $(\mathrm{p}<0.05)$. 
In particular, some specific differences were found in parental behavior of Brandt vole compared with another Lasiopodomys species, L. mandarinus. Contrary to the present results, absence of sex difference both in time spent with young and nest maintenance, decrease of pup grooming by female on the last stages of postnatal development, a high rate of male activity in bringing nest material, and active participation of female in pup retrieval are reported for the mandarin vole (Smorkatcheva, 2003). These differences in parental care could be explained by some contrast in main features of life history of Brandt and mandarin voles. The latter is known to specialize to subterranean mode of life, with biparental rearing system and high rate of activity of male in nest construction, digging tunnels, and foraging (Smorkatcheva, 1999, 2001). Thus, the performance of most of energetically expensive activities by male could be considered as additional paternal investment into successful survival of the female and offspring (Smorkatcheva, 2003). Brandt vole is not an obligatory fossorial rodent, and males of this species are less expected to contribute much in nest construction, digging and foraging. Such a prediction corresponds with present findings indicating less indirect paternal care, i.e. manipulations with bedding, bringing nest material and food cashing, in Brandt vole compared with mandarin vole. Nevertheless, more high values of such parental activities as time spent with young, time spent alone in the nest, and parental retrieval in males compared with females indicate a high rate of direct paternal care that could be related to a family group mode of life of Brandt vole.

In addition, I can conclude that explanation of Baverstock \& Green (1975) and Friedman et al. (1981) for motivation of pup grooming in rodents is not so correct. These authors suggested that maternal grooming (licking pups) is related mainly to ingestion of urine from their young to alleviate the additional requirements for water imposed by lactation. But paternal grooming cannot be imposed by lactation. There are some evidences that pup grooming, especially paternal one, is a form of additional tactile stimulation of offspring that is necessary for their normal physiological development, and perhaps, for its socialization. However, to answer this question, further investigations are needed.

As for paternal care, it often indicates a monogamous mating system (Kleiman, 1977), but is also predicted for certain polygamous systems like one-male harems (Eisenberg et al., 1972; Thomas \& Birney, 1979). Judging from composition of elementary social units in natural populations of Brandt and mandarin voles (Smorkatcheva et al., 1990; Shi et al., 1998; Wan et al., 1998; Smorkatcheva, 1999; Zöphel, 1999), polygamous mating system and monogamy could be expected in both Lasiopodomys species. Kleiman (1977) listed seven types of paternal care that is characteristic of monogamous mammals. Four of these, grooming of young, retrieval of young, nest construction and food cashing, were described previously for several arvicoline rodents (Oliveras \& Novak, 1986; Smorkatche- va, 2003; Libhaber \& Eilam, 2004) and in this paper for the Brandt vole, as well. Additionally, both males and females defend the family group territory by chasing intruders (Gromov, 2003), and territorial behaviour could be regarded as an indirect form of defence of young, too. Besides, males help to socialize the young due to direct parental care providing high rate of social interactions, including grooming and other tactile contacts. Thus, male Brandt voles apparently participate in all aspects for paternal care known for mammals.

Natural selection has obviously favoured the evolution of a high degree of paternal care in the Brandt vole, as well as in mandarin vole and some other microtine species like prairie vole, Microtus ochrogaster. Unfortunately, it is not yet known which ecological conditions led to evolution of the family group mode of life with biparental care in Brandt vole. On the one hand, one easily can imagine that such a mode of life of genus Lasiopodomys has been evolved due to specialization to subterranean mode of life (Burda, 1990; Smorkatcheva, 2003). In this case, an ancestor of recent Lasiopodomys species could be more relative to the mandarin vole, and in Brandt vole being adapted to another ecological niche, indirect paternal contribution to care of young would be later reduced. On the other hand, family group mode of life with biparental care could be evolved under ecological conditions which were similar to that ones of Microtus ochrogaster, i.e. arid habitats with sporadic distribution of scarce and valuable resources that forced the species to form monogamous pairs or one-male harems occupying defended territories; within such a territory both parents and their offspring are needed to cooperate their efforts to utilize and defend the resources. In that case, the ancestor of recent Lasiopodomys species could be more relative to the Brandt vole, and the mandarin vole would be originated later due to the adaptation to subterranean mode of life. Thus, there is a question: which of two Lasiopodomys species has originated earlier? Answer this question seems to be important for understanding the evolution of sociality in rodents.

ACKNOWLEDGEMENTS. I am grateful to Yu. Kovalskaya for providing the animals for the study. The research was partially supported by the Russian Foundation for the Basic Research grant 02-04-48419.

\section{References}

Baverstock P. \& Green B. 1975. Water recycling in lactation // Science. Vol.187. No.4177. P.657-658.

Burda H. 1990. Constraints of pregnancy and evolution of sociality in mole-rats with special reference to reproductive and social patterns in Cryptomys hottentotus (Bathiergidae, Rodentia) // Zeitschrift für Zoologische Systematik und Evolutionsforschung. Bd.28. Hf.1. P.26-39.

Eisenberg J., Muckenhirn N. \& Rudan R. 1972. The relation between ecology and social structure in primates // Science. Vol.176. No.4037. P.863-874.

Friedman M.I., Bruno J.P. \& Alberts J.R. 1981. Physiological and behavioral consequences in rats of water recy- 
cling during lactation // Journal of Comparative and Physiological Psychology. Vol.95. No.1. P.26-35.

Getz L.L. \& Carter C.S. 1996. Prairie-vole partnership // American Scientist. Vol.84. P.56-62.

Gromov V.S. 2001. [Behaviour of Brandt vole (Lasiopodomys brandti Radde, 1852) in captivity. 1. Social structure of family groups] // Zoologicheskii Zhurnal. T.80. No.12. P.1501-1508 [in Russian with English summary].

Gromov V.S. 2002. [Behaviour of Brandt vole (Lasiopodomys brandti Radde, 1852) in captivity. 2. Use of space and social organization in large open enclosures] // Zoologicheskii Zhurnal. T.81. No.1. P.1-6 [in Russian with English summary].

Gromov V.S. 2003. [Territorial structure and social organization in Brandt vole (Lasiopodomys brandti) under semi-natural conditions] // Zoologicheskii Zhurnal. T.82. No.7. P.852-861 [in Russian with English summary].

Kleiman D.G. 1977. Monogamy in mammals // Quarterly Review of Biology. Vol.52. No.1. P.39-69.

Libhaber N. \& Eilam D. 2004. Parental investment in social voles varies and is relatively independent of litter size // Journal of Mammalogy. Vol.85. No.4. P.748-755.

Lonstein J.S. \& De Vries G.J. 1999. Comparison of the parental behavior of pair-bonded female and male prairie voles (Microtus ochrogacter) // Physiology and Behavior. Vol.66. No.4. No.1. P.33-40.

McGuire B. \& Novak M. 1984. A comparison of maternal behaviour in the meadow vole (Mictotus pennsylvani$c u s)$, prairie vole (M. ochrogaster) and pine vole ( $M$. pinetorum) // Animal Behaviour. Vol.32. No.4. P.11321141.

Oliveras D. \& Novak M. 1986. A comparison of paternal behavior in the meadow vole, Microtus pennsylvanicus, the pine vole, Microtus pinetorum, and prairie vole, Microtus ochrogaster // Animal Behaviour. Vol.34. No.2. P.519-526.

Shi D., Hai S., Zheng S. \& Zhang Z. 1998. Studies of social behaviour in colonies of Brandt's vole (Microtus brandti) // International Conference on Rodent Biology and Management. October 5-9, 1998. Beijing, China. Abstracts of Papers. P.71.

Smorkatcheva A.V. 1999. The social organization of the mandarin vole, Lasiopodomys mandarinus, during the reproductive period // Zeitschrift für Säugetierkunde. Vol.64. Hf.6. P.344-355.

Smorkatcheva A.V. 2001. [On the distribution and ecology of the mandarin vole, Lasiopodomys mandarinus in Buryatiya] // Trudy Zoologicheskogo Instituta RAN. T.288. P.188-204 [in Russian with English summary].

Smorkatcheva A.V. 2003. Parental care in the captive mandarin vole, Lasiopodomys mandarinus // Canadian Journal of Zoology Vol.81. No.8. P.1-7.

Smorkatcheva A.V., Aksenova T.G. \& Zorenko T.A. 1990. [The ecology of Lasiopodomys mandarinus (Rodentia, Cricetidae) in the Transbaikal area] // Zoologicheskii Zhurnal. T.69. No.1. P.115-124 [in Russian with English summary].

Stern J.M. \& Johnson S.K. 1990. Ventral somatosensory determinants of nursing behaviour in Norway rats: 1 . Effect of variations in the quality of pup stimuli // Physiology and Behavior. Vol.47. No.5. P.993-1011.

Thomas J.A. \& Birney E.C. 1979. Parental care and mating system of the prairie vole, Microtus ochrogaster // Behavioural Ecology and Sociobiology. Vol.5. No.2. P.171186.

Wan X., Wang M., Zhong W. \& Wang G. 1998. The social structure and mating system of the Brandt vole (Microtus brandti) // International Conference on Rodent Biology and Management. October 5-9, 1998. Beijing, China. Abstracts of Papers. P.89.

Zöphel U. 1999. Social organization of the vole Microtus brandti inhabiting steppes of Central Asia // Proceedings of $3^{\text {rd }}$ European Congress of Mammalogy. May 29-June 2, 1999. Finland. P.242. 